\title{
Expression of NGF Receptor in the Developing and Adult Primate Central Nervous System
}

\author{
Gina C. Schatteman, ${ }^{1}$ Lorraine Gibbs, ${ }^{1}$ Anthony A. Lanahan, ${ }^{1}$ Philippa Claude, ${ }^{2}$ and Mark Bothwell' \\ ${ }^{1}$ Department of Physiology and Biophysics, University of Washington, Seattle, Washington 98195, and ${ }^{2}$ Wisconsin \\ Regional Primate Research Center, University of Wisconsin, Madison, Wisconsin 53715
}

\begin{abstract}
Monoclonal antibodies against human NGF receptor have been used for immunocytochemical localization of NGF receptors in the CNS of macaques and baboons at various stages of development. In the adult, neurons in most brain regions are devoid of detectable NGF receptors. However, abundant NGF receptor immunoreactivity is present on a population of neurons in basal forebrain, whlch, on the basis of appearance and pattern of distribution, probably correspond, at least in part, to magnocellular cholinergic neurons of this region. NGF receptors were also associated with the vasculature in most brain regions. NGF receptor immunoreactivity is present on Mueller glia of neural retina. In macaque fetuses, approximately 1 month prenatally, retinal Mueller glia possess lower levels of receptor, while higher levels of receptor are present in the retinal nerve fiber layer. In fetal cerebellum, abundant receptor immunoreactivity is present on Purkinje cells, granule cells of the premigratory zone of the external granule layer, and neurons of the deep nuclei. Immunoreactivity decreases with subsequent development and is absent in the adult. In cerebellum, levels of NGF receptor assayed by affinity crosslinking to radioiodinated NGF, and levels of NGF receptor mRNA assayed by Northern blot analysis decrease dramatically during the last month of fetal life.
\end{abstract}

The functional roles of NGF have been studied extensively in the PNS. The importance of NGF for development of sympathetic, sensory, and enteric nerve cells is well documented. However, only recently has it become clear that NGF may function in the CNS as well. While early studies focused on CNS catecholaminergic neurons, the responsiveness of these cells to NGF remains unclcar. In amphibians, NGF stimulates regeneration of severed optic nerve (Turner and Glaze, 1977). In higher vertebrates, where optic nerve regeneration does not occur, no NGF effect has been reported. In Xenopus tadpoles, brain aminergic and peptidergic neurons are responsive to NGF (Levi-Montalcini and Aloe, 1985). However, in mammalian brain, NGF

\footnotetext{
Received Mar. 18, 1987; revised Sept. 10, 1987; accepted Sept. 10, 1987.
}

This work was supported by NSF Grant DMB-8544656 and NIH Grant NS23343 to M.B. and by the base operating grants of the Wisconsin Regional Primate Research Center (NIH Grant RR00167) and the Regional Primate Research Center at the University of Washington (NIH Grant RR00166). We wish to thank Parada, P. Brigham, J. Johnson, and Dr. H. Uno for their assistance in this work. Correspondence should be addressed to Dr. Mark Bothwell, Department of Physiology and Biophysics, SJ-40, University of Washington, Seattle, WA 98195. Copyright (C) 1988 Society for Neuroscience $0270-6474 / 88 / 030860-14 \$ 02.00 / 0$ responsiveness has been well documented only in cholinergic neurons. The addition of NGF to serum-free aggregating cell cultures of fetal rat telencephalon greatly stimulates the developmental increase in CAT activity (Honegger and Lenoir, 1982). NGF also raises CAT levels in cultured septal cholinergic neurons (Hefti et al., 1985; Martinez et al., 1985). In neonatal rats, CAT activity is increased in the septum, hippocampus, cortex, and corpus striatum after intraventricular injection of NGF (Gnahn et al., 1983; Mobley et al., 1985). ${ }^{125}$ I-NGF injected into the frontal or dorsal anterior occipital cortex of adult rats is specifically taken up and transported retrogradely to large cholinergic neurons in the nucleus basalis. Other nuclei known to project to this region of the cortex are unlabeled (Seiler and Schwab, 1984). Specific binding of radiolabeled NGF to magnocellular cholinergic neurons in tissue sections of rat basal forcbrain has been reported (Richardson et al., 1986). Regionally localized synthesis of NGF appears to correlate with fields of innervation of these cholinergic neurons, with highest levels of NGF mRNA being found in hippocampus and cortex (Shelton and Reichardt, 1984; Korshing et al., 1985). Taken together, these studies suggest that NGF produced in cerebral cortex and in hippocampus provides trophic support to the magnocellular cholinergic neurons of basal forebrain.

We have developed monoclonal antibodies that recognize the cell surface NGF receptor of the primate PNS (Ross et al., 1984; Marano et al., 1987), as well as cDNA clones of the human NGF receptor (Johnson et al., 1986). Using these specific probes, we have undertaken studies to determine whether the NGF responsiveness of CNS neurons is mediated by the same receptor protein that functions in the PNS. In addition, we have sought the presence of NGF receptors in brain regions outside of those where an NGF response has been reported, in the expectation that such studies might point to hitherto unrecognized roles of NGF in the brain.

While this manuscript was in preparation, 2 reports appeared describing immunochemical characterization of NGF receptor localization in brain (Hefti et al., 1986; Taniuchi et al., 1986). In substantial agreement with these results, we report that large neurons of the basal forebrain (apparently magnocellular cholinergic neurons) express high levels of NGF receptor. In addition, however, our results reveal the presence of NGF receptors on a variety of other CNS cell types. In this report we describe the expression of NGF receptors on glia of optic nerve and neural retina, and, during a discrete period of fetal cerebellar development, on Purkinje cells, granule cells of the premigratory zone of the external granular layer, and neurons of deep nuclei as well as on pia mater. 


\section{Materials and Methods}

Acquisition and storage of tissues. Tissues from macaques (Macaca fascicularis, nemestrina, and mulatta) and baboons (Papio anubis and cynocephalus) were obtained from the Tissue Distribution Programs of the Regional Primate Research Centers at the University of Washington and the University of Wisconsin. Results obtained with various macaque species and with various baboon species did not differ significantly. Thus, animals will be referred to subsequently generically as macaques and baboons.

All work involving fetal tissue employed Macaca mulatta. Fetuses were obtained by caesarian section as part of an unrelated study. In several cases, tissues were obtained from fetuses that had been exposed to dexamethasone in utero as part of an unrelated research project. Where we were able to compare results of animals with and without dexamethasone exposure, no differences were observed, leading us to believe that dexamethasone exposure was irrelevant to our studies. However, in the case of results presented for levels of NGF receptor mRNA in $133 \mathrm{~d}$ macaque fetus, tissue was obtained only from a dexamethasone-exposed animal, and we have not had the opportunity to confirm that comparable results would be obtained with an untreated animal.

All tissues were dissected within 1-2 hr after sacrifice of animals, and were fixed for periods up to 2 weeks in methyl Carnoy's fixative for immunocytochemistry, or were frozen in liquid nitrogen and stored at $-80^{\circ} \mathrm{C}$ until use for biochemical analysis.

Immunocytochemistry. Fixed tissues were embedded in paraffin, sectioned at 6 or $10 \mu \mathrm{m}$, deparaffinized in xylene, rehydrated through graded alcohols, and reacted $15 \mathrm{~min}$ with $0.75 \%$ hydrogen peroxide to inactivate endogenous peroxidases. Nonspecific staining was blocked by preincubation of sections $45 \mathrm{~min}$ with $2.5 \%$ horse serum and $2.5 \%$ macaque serum in Dulbecco's PBS. Primary and secondary antibodies were diluted in this same solution. Tissues were incubated $1 \mathrm{hr}$ with NGF receptor antibody [either ascites fluid or purified $\mathrm{IgG}$ from hybridomas NGFR3, NGFR4, or NGFR5 (Marano et al., 1987)] or control antibody [either ascites fluid containing irrelevant monoclonal antibodies (antiHerpes I or C10-7) or nonimmune mouse IgG] at $1.5 \mu \mathrm{g} / \mathrm{ml}$ of IgG. Sections were then washed and treated with biotinylated horse antimouse serum, washed again, and incubated with avidin-biotin HRP complex using the Vectastain $\mathrm{ABC}$ kit of Vector Laboratories according to the manufacturer's instructions. A solution of $0.3 \%$ hydrogen per-

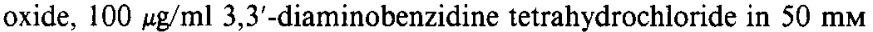
Tris- $\mathrm{HCl}, \mathrm{pH} 7.6$, was used as substrate for the immunolocalized peroxidase, resulting in a brown reaction product.

$N G F$ receptor extraction and affinity labeling. NGF receptors were labeled by crosslinking to radioiodinated NGF, using a modification of the procedure of Marano et al. (1987). NGF was radioiodinated to a specific activity of $50-100 \mathrm{cpm} / \mathrm{pg}$ (Schechter and Bothwell, 1981). Fresh or frozen tissues were homogenized using a glass dounce homogenizer, in $50 \mathrm{~mm}$ Hepes, $5 \mathrm{mM} \mathrm{MgCl}_{2}, 1 \mathrm{~mm}$ EDTA, $20 \mathrm{kU} / \mathrm{ml}$ aprotinin, 0.2 $\mathrm{mm}$ tosyl lysine chloroketone, $2 \mathrm{~mm}$ phenylmethane sulfonylfuoride, $1 \%$ Triton X-100, pH 8.0 (homogenization buffer), and the homogenate was subjected to 4 cycles of vortex mixing $(30 \mathrm{sec}$ ) followed by cooling on ice (5 min). Homogenates were centrifuged $5 \mathrm{~min}$ at $1000 \times \mathrm{g}$, and the supernatants were collected and further clarified by centrifugation, $45 \mathrm{~min}$ at $10,000 \times \mathrm{g}$. Protein concentrations in supernatants were determined by the method of Sedmak and Grossberg (1977), and supernatants were diluted to equivalent protein concentrations in homogenization buffer. Supernatant $(25 \mathrm{ml}, 30-50 \mathrm{mg} / \mathrm{ml}$ protein) was adjusted to $\mathrm{pH} 6.5$ and incubated with ${ }^{125} \mathrm{I}-\mathrm{NGF}(20 \mathrm{ng} / \mathrm{ml})$ for $30 \mathrm{~min}$, $37^{\circ} \mathrm{C}$. Ethyldimethylaminopropylcarbodiimide (EDAC) was added to a final concentration of $4 \mathrm{~mm}$, and the mixture was incubated $15 \mathrm{~min}$ at $23^{\circ} \mathrm{C}$ with occasional mixing, then clarified by centrifugation, $2 \mathrm{~min}$ at $10,000 \times g$

Immunoprecipitation. The above extracts, containing NGF receptor crosslinked to radiolabeled NGF, were adjusted to $\mathrm{pH} 7.5$ and were subjected to immunoprecipitation as follows: extract $(800-900 \mu$ l) was incubated $1 \mathrm{hr}$ at $23^{\circ} \mathrm{C}$ with $4-5 \mu \mathrm{l}$ of ascites fluid from mice bearing intraperitoneal tumors derived from NGF receptor hybridomas NGFR3, NGFR4, or NGFR5, then for an additional $2 \mathrm{hr}$ at $0^{\circ} \mathrm{C}$ with $12 \mu \mathrm{l}$ goat anti-mouse $\mathrm{IgG}$ (Miles Laboratories, $1 \mathrm{mg} / \mathrm{ml}$ ). Formalin-fixed Cowan strain Staphylococcus aureus cells were washed by preparing a $10 \%$ suspension in $25 \mathrm{~mm}$ Hepes, $1 \%$ Triton X-100, 0.5\% NP-40, 0.1\% SDS, $150 \mathrm{~mm} \mathrm{NaCl}, 1 \mathrm{mg} / \mathrm{ml} \mathrm{BSA}, \mathrm{pH} 8.0$ (washing buffer), then pelleted by centrifugation; this procedure was repeated twice. The final pellet was taken up as a $10 \%$ suspension in $25 \mathrm{~mm}$ Hepes, $1 \%$ Triton X-100, 1 $\mathrm{mg} / \mathrm{ml}$ serum albumin, $\mathrm{pH} 8.0$ (suspension buffer). Washed $S$. aureus cells, $125 \mu \mathrm{l}$, were added to the immune complex mixture and incubated with mixing for $1 \mathrm{hr}$ at $23^{\circ} \mathrm{C}$. The $S$. aureus cells were pelleted and rcsuspended once in washing buffer and twice in suspension buffer before centrifugation through a cushion of $10 \%$ sucrose in washing buffer. The above procedures were performed using a Beckman Microfuge.

Gel electrophoresis and autoradiography. Final $S$. aureus pellets from above were suspended in $40 \mu \mathrm{l}$ sample buffer $(0.1 \mathrm{M}$ Tris- $\mathrm{HCl}, 10 \%$ glycerol, $1 \%$ SDS, $0.001 \%$ bromophenol blue, $10 \%$ 2-mercaptoethanol, $\mathrm{pH} \mathrm{6.8),} \mathrm{boiled} 7 \mathrm{~min}$, and centrifuged $1 \mathrm{~min}$ at $10,000 \times \mathrm{g}$; the supernatant was subjected to SDS-PAGE on gels of $10 \%$ acrylamide, according to Laemmli (1970). Gels were stained with Coomasie blue, dried, and exposed to Kodak XAR-5 film with Cronex Lightening Plus intensifying screens for $1-10 \mathrm{~d}$ at $-80^{\circ} \mathrm{C}$.

$R N A$ preparation. Glassware was baked at $240^{\circ} \mathrm{C}$ overnight and, when possible, disposable plasticware was used. Solutions were treated with $0.1 \%$ diethylpyrocarbonate overnight and autoclaved; solutions containing Tris were treated with diethylpyrocarbonate prior to addition of Tris. Total RNA was extracted from frozen and fresh tissues by a modification of the method of Chirgwin et al. (1979). Intact tissues were homogenized in $4 \mathrm{~m}$ guanidinium isothiocyanate, $50 \mathrm{~mm}$ Tris, $\mathrm{pH} 7.6$, $10 \mathrm{~mm}$ EDTA, 2\% sarkosyl, 1\% 2-mercaptoethanol (homogenization buffer) using a Waring blender, and samples were extracted once with hot phenol (Feramisco et al., 1982) and the nucleic acids precipitated with EtOH. The nucleic acid pellet was resuspended in homogenization buffer, and solid $\mathrm{CsCl}$ was added to $0.2 \mathrm{gm} / \mathrm{ml}$. The sample was layered

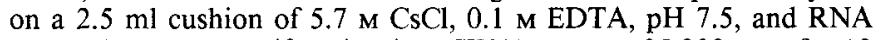
was pelleted by centrifugation in a SW41 rotor at $35,000 \mathrm{rpm}$ for 18 hr. RNA pellets were resuspended in $\mathrm{H}_{2} \mathrm{O}$ containing $40 \mathrm{U} / \mathrm{ml} \mathrm{RNasin}$ (Promega Biotec) and precipitated with EtOH. Poly $(\mathrm{A}+) \mathrm{RNA}$ was selected by 1 or 2 cycles of chromatography on oligo(dT)-cellulose (Aviv and Leder, 1972). RNA was quantitated by measuring $A_{260}$ and $A_{280}$.

Northern blot analysis. Total and poly $(\mathrm{A}+) \mathrm{RNA}$ samples were denatured with formaldehyde and subjected to electrophoresis on $1.5 \%$ agarose/2.2 $\mathrm{m}$ formaldehyde gels (Lehrach et al., 1977) then transferred to nitrocellulose paper using 20X SSC (IX SSC $=0.15 \mathrm{M} \mathrm{NaCl}, 0.015 \mathrm{~m}$ sodium citrate, $\mathrm{pH} 7.0$ ) without treating the gel (Thomas, 1980). After baking, blots were prehybridized overnight at $37^{\circ} \mathrm{C}$ in $50 \%$ formamide, $0.1 \%$ SDS, $5 \mathrm{X}$ Denhardt's solution (50X Denhardt's solution $=1 \%$ BSA, $1 \%$ polyvinylpyrolidone, $1 \%$ Ficoll), $0.1 \mathrm{mg} / \mathrm{ml}$ sheared denatured salmon sperm DNA, and 6X SSPE (1X SSPE $=0.15 \mathrm{~m} \mathrm{NaCl}, 10 \mathrm{~mm}$ $\mathrm{NaH}_{2} \mathrm{PO}_{4} \cdot \mathrm{H}_{2} \mathrm{O}, 1.1 \mathrm{~mm}$ EDTA, pH 7.4) and then hybridized at $37^{\circ} \mathrm{C}$ for $3 \mathrm{~d}$ in $50 \%$ formamide $0.1 \%$ SDS, 1X Denhardt's solution, $200 \mathrm{gm} /$ $\mathrm{ml}$ sheared denatured salmon sperm DNA, 6X SSPE, and $4 \mathrm{ng} / \mathrm{ml}$ denatured nick-translated cDNA probe (Rigby et al., 1977) at a specific activity of $4 \times 10^{9} \mathrm{cpm} / \mathrm{gm}$. Blots were washed for $1 \mathrm{hr}$ at $22^{\circ} \mathrm{C}$ with 4 changes of $2 \mathrm{X} \mathrm{SSC}, 0.2 \%$ SDS, then for $2 \mathrm{hr}$ at $22^{\circ} \mathrm{C}$ with 4 changes of $0.1 \times$ SSC, $0.2 \%$ SDS; the final wash was for $2 \mathrm{hr}$ at $60^{\circ} \mathrm{C}$ with 2 changes of $0.1 \mathrm{X} \mathrm{SSC}, 0.2 \%$ SDS. Filters were exposed to Kodak XAR-5 film with a DuPont Cronex intensifying screen at $-80^{\circ} \mathrm{C}$. Autoradiograms were used to locate hybridizing bands on the filter, which were excised and assayed for radioactivity in Aquasol (New England Nuclear) on a scintillation counter.

\section{Results}

NGF receptor immunoreactivity was localized in brain sections using an immunoperoxidase procedure as described in Materials and Methods. Results obtained using 3 different NGF receptor monoclonal antibodies were indistinguishable. Results shown were obtained with antibody NGFR5. Cerebral cortex and cerebellum were removed, and samples from representative regions were sectioned and immunostained. The remainder of the diencephalon and telencephalon was studied by slicing coronally or sagitally at approximately $0.5 \mathrm{~cm}$ intervals, and each region was sectioned and immunostained.

\section{The vasculature}

In most regions of the adult brain, the most pronounced NGF receptor immunoreactivity was associated with the vasculature. The immunostaining was particularly intense at external brain surfaces, where capillaries and arterioles adhere to the pia mater, 


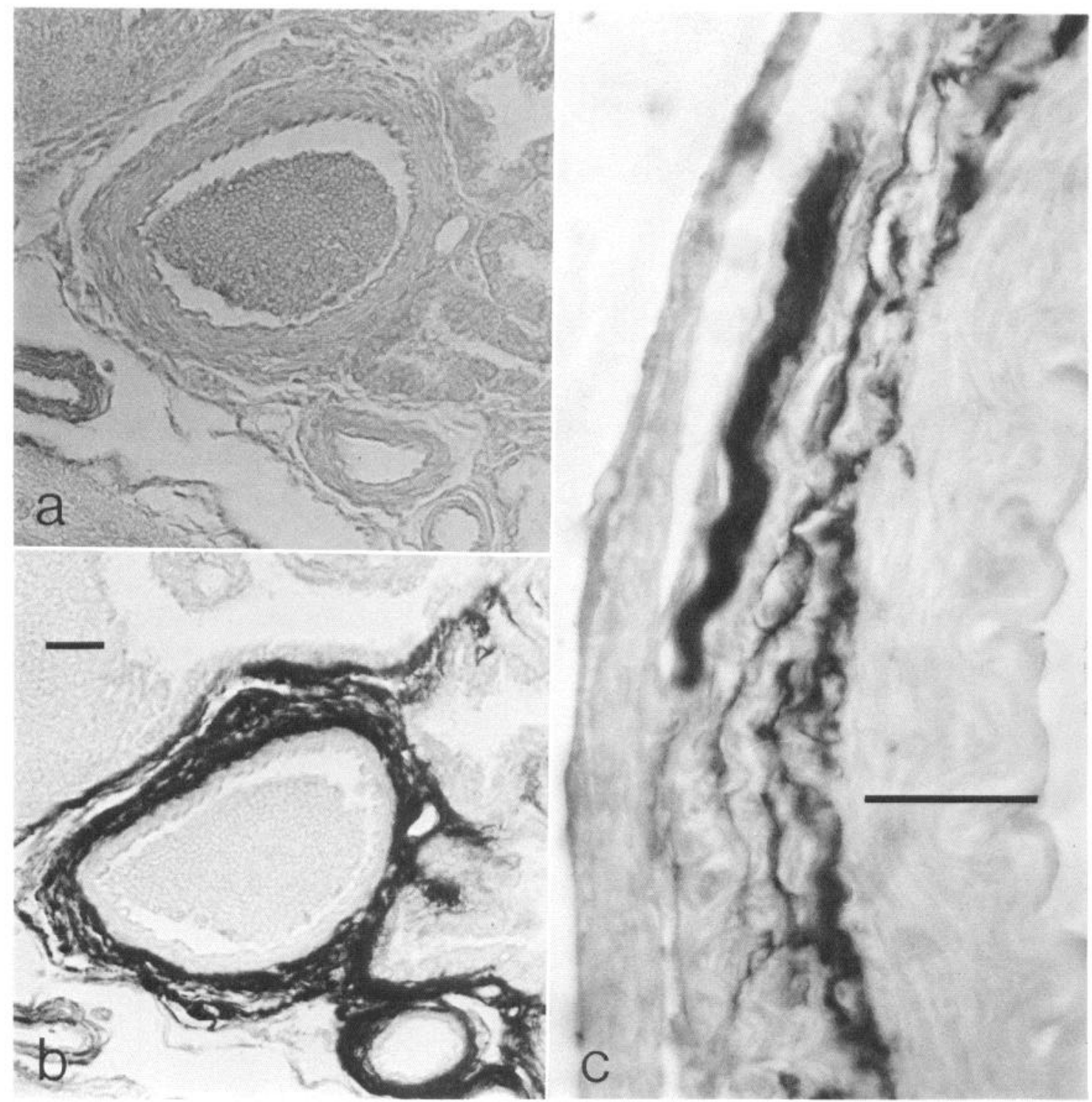

Figure 1. NGF receptor immunostaining in choroid plexus. Choroid plexus associated with cerebral cortex of baboon was processed for immunocytochemistry using nonimmune $\operatorname{IgG}(a)$ or NGFR5 monoclonal antibody $(b, c)$ as primary antibody. Scale bar, $20 \mu \mathrm{m}$.

and in the choroid plexus (Fig. 1). The presence of NGF receptors in vascular tissue is not unexpected, because the vasculature receives sympathetic innervation. The pattern of staining shown in Figure 1 is consistent with sympathetic innervation of the smooth muscle layer of choroid plexus. The extensive nature of this immunostaining probably reflects, in part, the presence of NGF receptors not only on sympathetic axons but also on associated Schwann cells (Ross et al., 1984; G. C. Schatteman, unpublished observations). Similar patterns of immunostaining have been seen to be associated with the vasculature outside the brain.

\section{Neurons of basal forebrain}

Apart from the vasculature, most regions of the adult brain were devoid of NGF receptor immunoreactivity. Neuronal immunoreactivity was confined primarily to the area bounded dorsally by the anterior commissure, posteriorly by the hypothalamus, and anteriorly by the head of the caudate. In this area, large neurons of the substantia innominata, the basal olfactory region, and the ventral globus pallidus were found to be immunoreactive (Figs. 2 and 3). These immunoreactive neurons extended into the septal nucleus accumbens, the medial septal nucleus, and the globus pallidus-internal capsule border as well. In some animals, a few cells in the ventral part of the head of the caudate and the rostral-ventral putamen were also seen to be labeled.

Immunoreactivity was located on the cell bodies and proximal nerve fibers of these neurons, with staining present on the cell surface and within the cytoplasm but excluded from the nucleus (Fig. 3). The substantial degree of intracellular immunostaining is similar to that we have observed on sensory and sympathetic neurons (Marano et al., 1987; unpublished data) and apparently reflects receptors present on internal membrane compartments. The location and appearance of the immunostained basal forebrain neurons are consistent with the appearance and distribution of magnocellular cholinergic neurons. However, we have not determined whether these neurons are, in fact, cholinergic. 

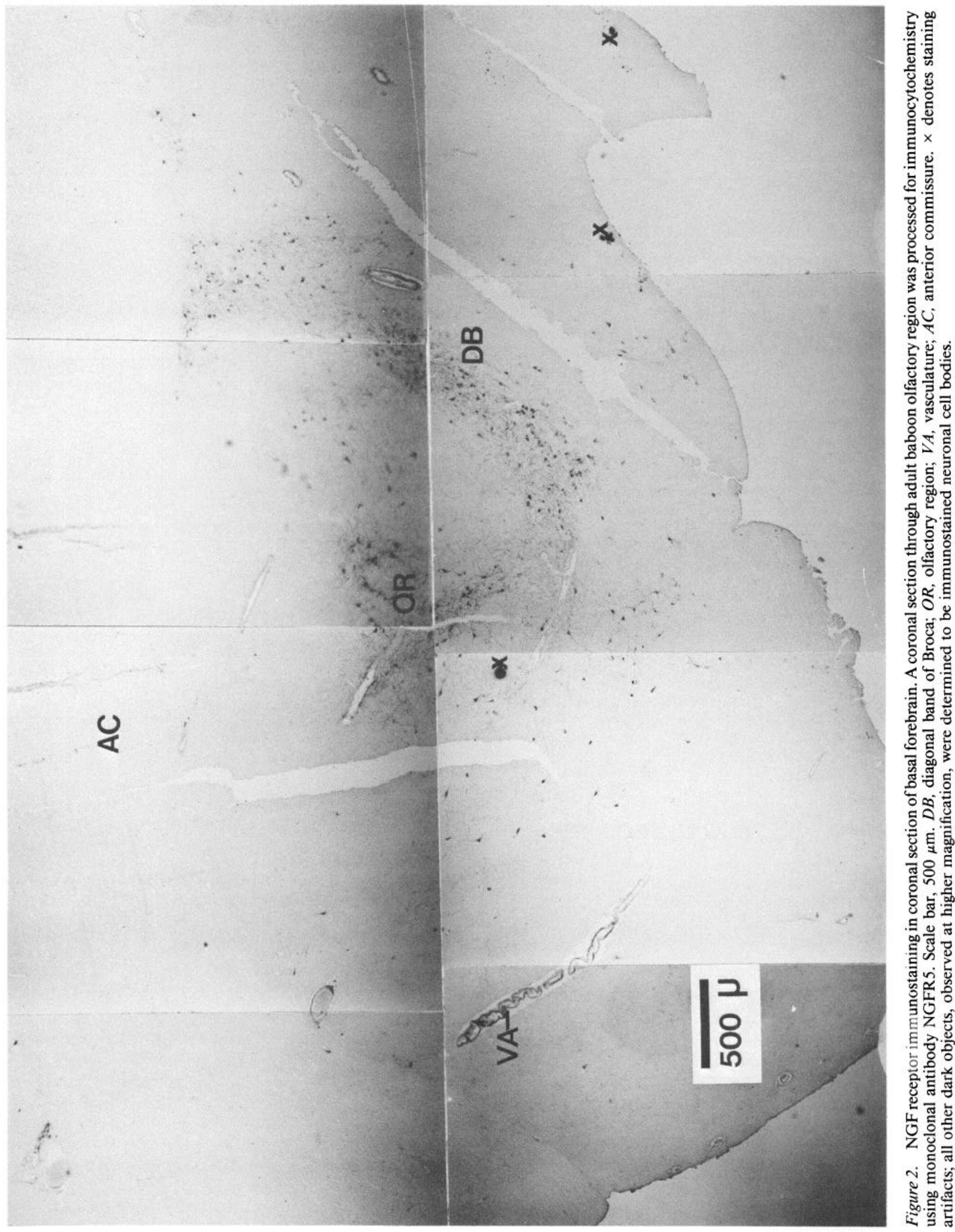


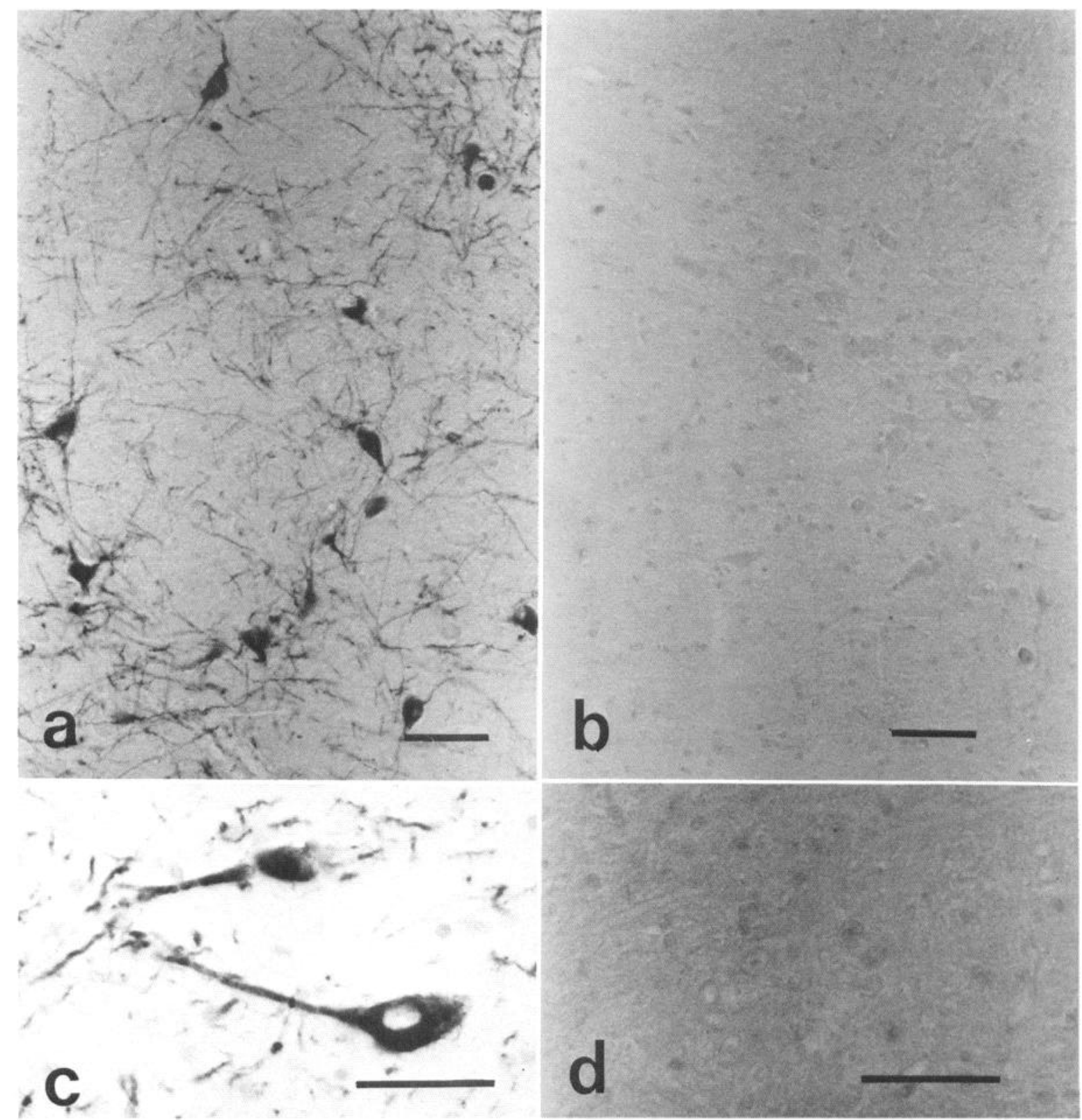

Figure 3. NGF receptor immunostaining of magnocellular cholinergic neurons in olfactory region. A section through olfactory region of an adult baboon was processed for immunocytochemistry using NGFR5 ( $a$ and $c$ ) or nonimmune mouse IgG $(b$ and $d$ ) as the primary antibody. Scale bar, $50 \mu \mathrm{m}$.

The pattern of immunostaining was similar in a $1 \mathrm{~d}$ neonate, except that the intensity of staining was slightly greater (data not shown).

The cholinergic neurons of basal forebrain send axonal projections to hippocampus and cortex. However, we have been unable to detect NGF receptor immunoreactivity on fiber projections to these regions.

\section{Cerebellum}

While adult cerebellum was essentially devoid of NGF receptor immunoreactivity, abundant immunostaining was observed in the macaque fetus at 133-134 d of gestation, and reduced immunoreactivity was present at $164 \mathrm{~d}$ of gestation (almost full term) (Figs. 4, 5). At $134 \mathrm{~d}$ of gestation, receptor immunoreactivity was present on Purkinje cell bodies and dendrites, on cells in the external granular layer, and, weakly, in the inner granular layer (Figs. 5a; 6, c, d) and in deep cerebellar nuclei (Fig. 4). Immunostaining of the Purkinje cell dendritic tree is most clearly resolved in Figure $6 c$, in which the plane of section is perpendicular to the planar Purkinje cell dendritic tree, resulting in a striated appearance in the molecular layer. At this stage of development, the external granular layer consists of 2 zones, referred to as the proliferative zone, containing round mitotic precursors of granule and other cells, and the premigratory zone, in which granule cells have assumed a bipolar shape as the first stage of migration and formation of parallel fibers (Altman, 1972). NGF receptor immunoreactivity is present on cell bodies and bipolar processes of granule cells of the premigratory zone (Fig. 7). The much lower level of immunoreactivity on granule cells of the inner granular layer suggests that NGF receptor 


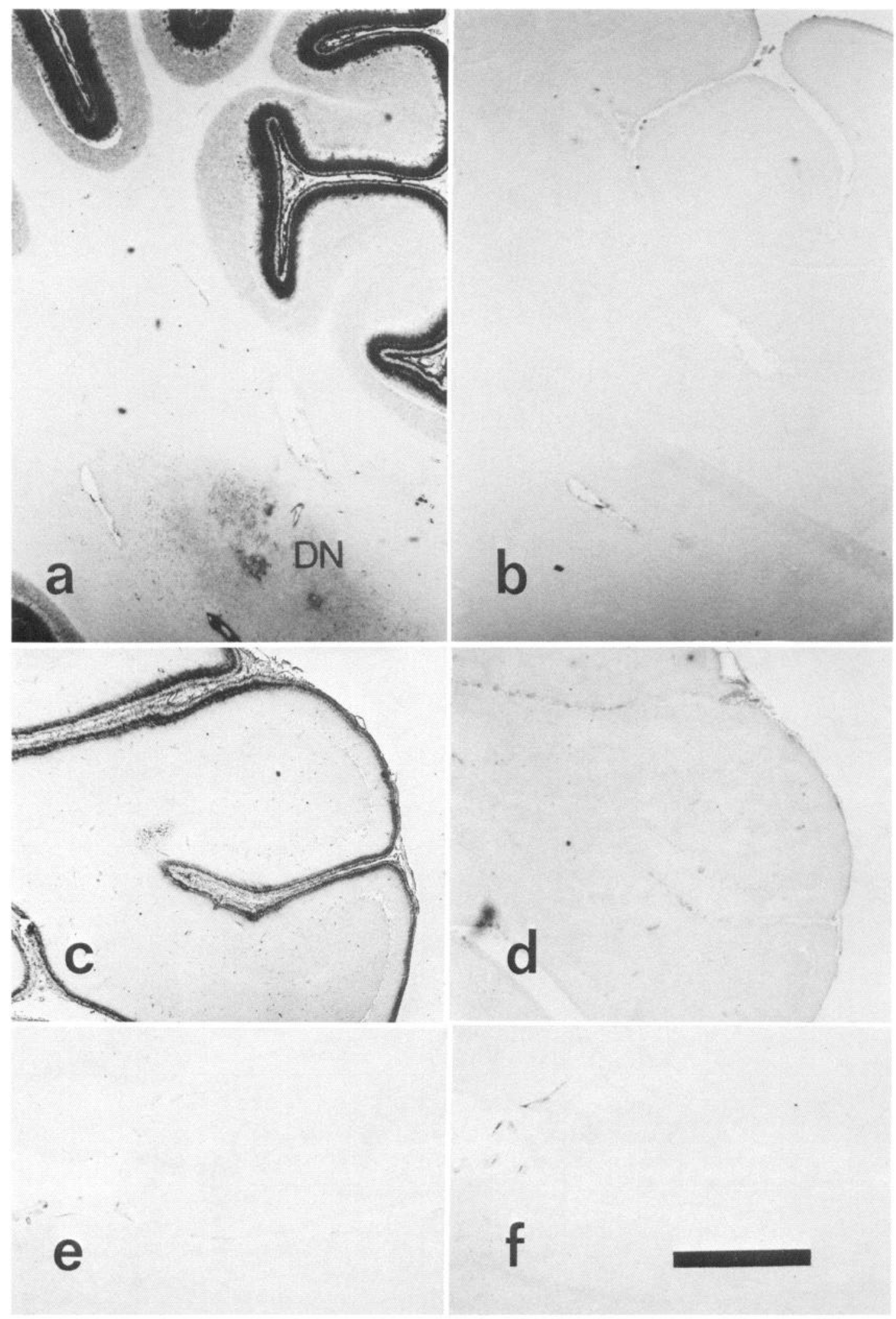

Figure 4. Developmental progression of NGF receptor expression in cerebellum viewed at low magnification. Sections through cerebellum of a macaque fetus at $134 \mathrm{~d}$ of gestation $(a$ and $b), 162 \mathrm{~d}$ of gestation $(c$ and $d)$, or at adulthood $(e$ and $f)$ were processed for immunocytochemistry using NGFR5 $(a, c, e)$ or nonimmune mouse $\operatorname{IgG}(b, d, f)$ as primary antibody. Scale bar, $500 \mu \mathrm{m}$. $D N$, deep nucleus. 


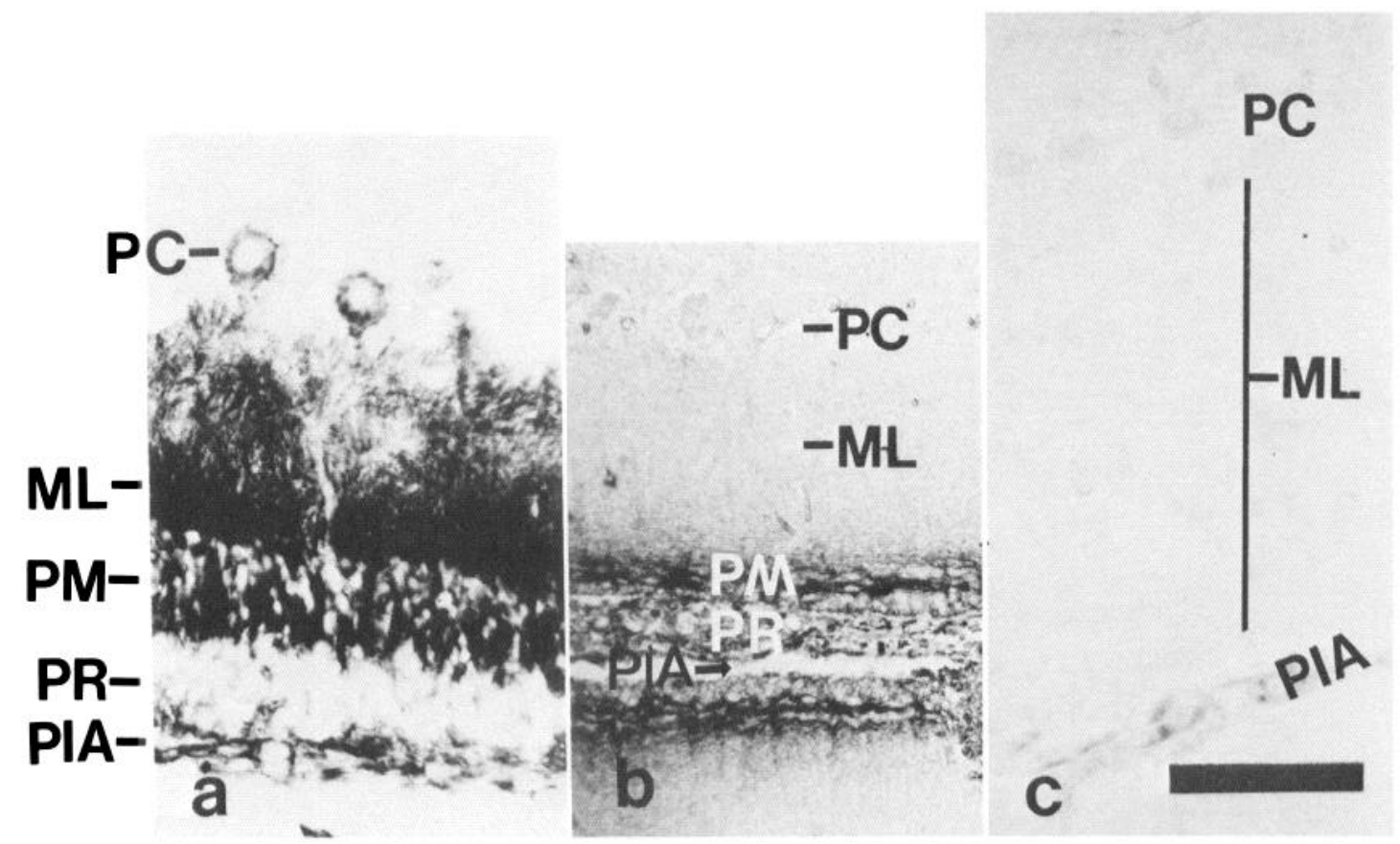

Figure 5. Developmental progression of NGF receptor expression in cerebellar molecular and external granular layers. Cerebellar sections of macaque were immunostained with NGFR5 antibody. Cerebellum samples were obtained from $134 \mathrm{~d}$ fetus $(a), 162 \mathrm{~d}$ fetus $(b)$, or adult $(c)$. Scale bar, $50 \mu \mathrm{m}$. $P R$, proliferative zone; $P M$, premigratory zone; $M L$, molecular layer (with Purkinje cell dendrites immunostained); $P C$, Purkinje cell bodies; PIA, pia mater.

expression must rapidly diminish as the granule cell bodies migrate into the inner granular layer. A lower, but significant, level of immunostaining of a fibrous nature is present in the proliferative zone of the external granular layer. The cellular origin of this staining is not clear. One possible source is Bergmann glia. Cell bodies of Bergmann glia reside in proximity to Purkinje cell bodies, while the processes of Bergmann glia extend to the pia. However, no immunostaining of Bergmann glial cell bodies was observed (Figs. $5 a, 6 d$ ). Additionally, staining of pia mater was observed (Figs. $5 a, 6 d$ ). Similar staining of pia mater occurs on cerebral cortex and elsewhere in the brain at this stage of development (data not shown). In the expectation that receptor immunoreactivity might be observed on Purkinje cell axon terminii, we examined deep cerebellar nuclei that receive Purkinje cell projections. Immunoreactivity was present on deep nuclei but was localized not only on nerve fibers, but also on neuronal cell bodies (Fig. $6 a$ ). Thus, it is not clear whether the nerve fiber immunostaining represents dendrites of the neurons intrinsic to the nuclei, axonal projections of Purkinje cells, or both.

At 161-164 d of gestation, immunostaining of Purkinje cells was no longer observed. Receptor immunoreactivity was restricted to the external granular layer, which is diminished in thickness at this developmental stage in comparison to $134 \mathrm{~d}$ of gestation.

\section{Neural retina}

Immunocytochemical examination of neural retina of adult animals revealed intense NGF receptor immunoreactivity (Fig. 8). Because of the close association of processes of Mueller glia with retinal neurons, it is difficult to determine whether immunostaining derives from Mueller glia, neurons, or both. However, the presence of NGF receptor immunoreactivity on Mueller cells may be inferred from the immunostaining of the charac- teristic villi of these cells, denoted by the arrow in Figure $9 a$. The pattern of staining is consistent with Mueller cell processes contributing much, if not all, of the retinal immunoreactivity. In fetal retina ( $135 \mathrm{~d}$ of gestation), very little immunoreactivity was detectable on Mueller cells (Fig. 8, $b, e$ ). However, intense immunoreactivity was observed in the nerve fiber layer. A section passing tangentially through the nerve fiber layer reveals immunostaining of nerve fibers but not of the ganglion cell bodies from which these nerve fibers derive (Fig. 9). While it is possible that NGF receptors are localized on ganglion cell axons but not cell bodies, we have not observed such a pattern of receptor distribution on other neuronal populations. It seems more likely that NGF receptor immunoreactivity of retinal nerve fibers derives from glial cells.

\section{Biochemical verification that brain immunoreactivity corresponds to authentic $N G F$ receptor}

To determine whether immunoreactivity observed in brain corresponds to authentic NGF receptor, we employed a method involving specifically labeling NGF receptors by covalent crosslinking to radioiodinated NGF. As described in Materials and Methods, detergent-extracted proteins of various brain regions were incubated with ${ }^{125} \mathrm{I}-\mathrm{NGF}$ followed by the crosslinker EDAC. NGF receptors affinity-labeled in this manner were then characterized by SDS-PAGE, followed by autoradiography of the dried gel. Specificity of labeling was assessed by control experiments in which $10 \mu \mathrm{g} / \mathrm{ml}$ unlabeled NGF was mixed with radiolabeled NGF. This permited us to determine whether immunoreactive material specifically binds NGF, and if so, whether the protein has a molecular weight comparable to that of the authentic NGF receptor. Additionally, we determined whether the labeled species was specifically immunoprecipitated by the NGF receptor monoclonal antibody, NGFR5. 


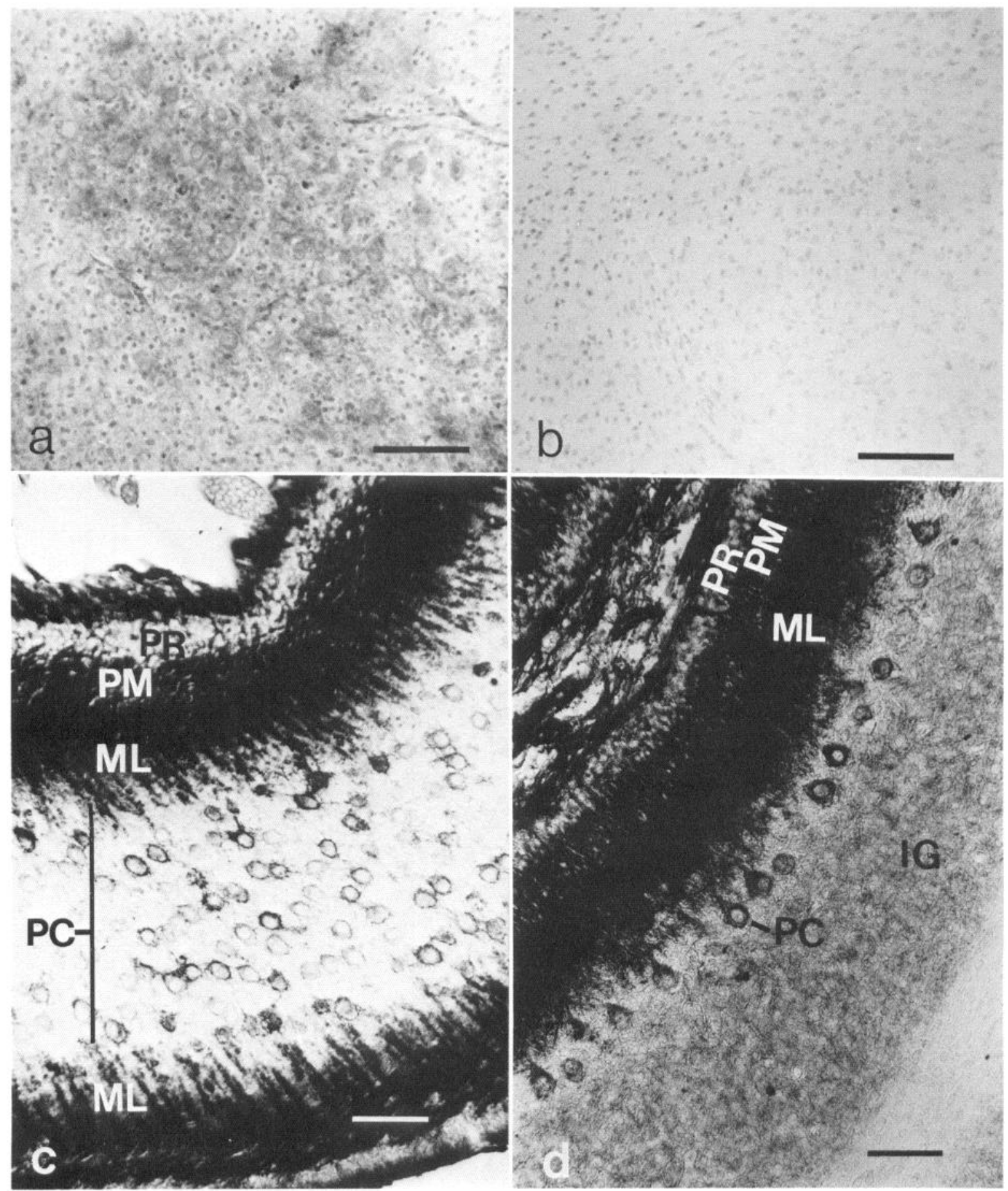

Figure 6. NGF receptor immunoreactivity in fetal cerebellum. Cerebellar sections from a $134 \mathrm{~d}$ macaque fetus were immunostained with NGFR5 $(a, c, d)$ or control IgG $(b) . a$ and $b$, deep cerebellar nucleus; $c$, cerebellum sectioned tangential to the cerebellar surface through the Purkinje cell body layer; $d$, cerebellum sectioned perpendicular to the cerebellar surface. Scale bar, $50 \mu \mathrm{m}$. $P R$, proliferative zone; $P M$, premigratory zone; $M L$, molecular layer (with Purkinje cell dendrites immunostained); $P C$, Purkinje cell bodies; $I G$, inner granular layer.

As shown in Figure 10, application of this procedure to homogenates of several brain regions yields an immunoprecipitable labeled species with a molecular weight $(97,000)$ indistinguishable from that obtained for the NGF-receptor complex of dorsal root ganglia and the human melanoma cell line A875, which express abundant NGF receptors. The mouse $\mathrm{L}$ cell line, which lacks NGF receptors, gives no comparable labeled species. Control experiments, some of which are not shown, demonstrate in all cases that $10 \mu \mathrm{g} / \mathrm{ml}$ unlabeled NGF prevents labeling of the receptor, and irrelevant monoclonal antibody does not immunoprecipitate the NGF-receptor complex. The 150,000200,000 Da species visible in some lanes represents an aggregated form of NGF receptor (Grob et al., 1985; Marano et al., 1987). The approximately $60,000 \mathrm{Da}$ labeled species is observed even in tissues devoid of NGF receptor such as liver and is obtained even in the presence of $10 \mu \mathrm{g} / \mathrm{ml}$ unlabeled NGF (data 


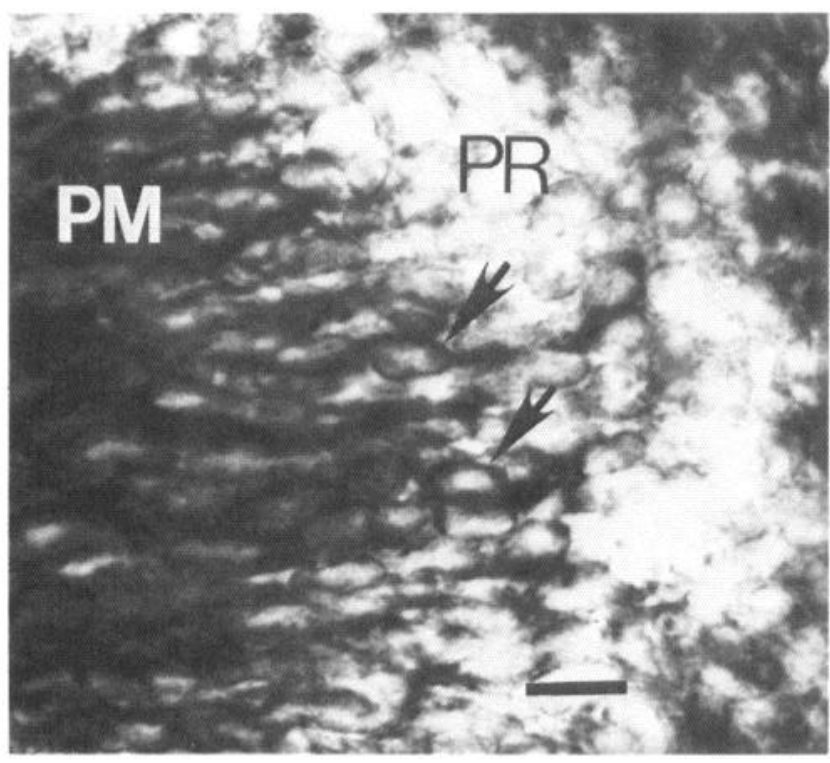

Figure 7. Immunostained granule cells of outer granular layer. Sections pass obliquely through proliferative $(P R)$ and premigratory $(P M)$ zones of the external granular layer. Arrows indicate several bipolar granule cells. Scale bar, $10 \mu \mathrm{m}$.

not shown). Thus, it appears to represent a nonspecific interaction. While levels varied from tissue to tissue, NGF receptors were detected in this manner in virtually every adult CNS region examined including brain stem, spinal cord, basal forebrain, cerebral cortex, corpus striatum, and cerebellum. While NGF receptors were detected in brain regions such as basal forebrain, where we have immunocytochemically localized NGF receptor immunoreactivity to neurons, low levels of NGF receptor were also detected in brain regions such as adult cerebellum, where the only NGF receptor immunoreactivity detected in the immunocytochemical procedure is associated with the vasculature. Thus, assay of NGF receptor localization by nonanatomical biochemical means may give a misleading picture of the distribution of NGF receptors on CNS neurons. However, the affinity labeling procedure revealed much higher levels of NGF receptor in fetal cerebellum in comparison with levels in adult cerebellum (Fig. 10A, lanes 4 and 5), supporting our conclusion that the immunoreactivity detected in fetal cerebellum by immunocytochemical means corresponds to authentic NGF receptor.

\section{$N G F$ receptor $m R N A$ in brain}

We also addressed the question of the authenticity of immunocytochemically identified cerebellar NGF receptors by determining whether NGF receptor mRNA is present. As shown in Figure $11 A$, Northern blot analysis, using a human NGF receptor cDNA probe, reveals that fetal cerebellum contains a hybridizing mRNA similar in size (3.8 kilobases) to the NGF receptor mRNA found in dorsal root ganglia and in the A875 human melanoma cell line. Lower but significant receptor mRNA levels were detected in adult cerebellum and in other brain regions, upon longer autoradiographic exposure of the blot (data not shown). Figure $11 \mathrm{~A}$ also demonstrates the presence of low
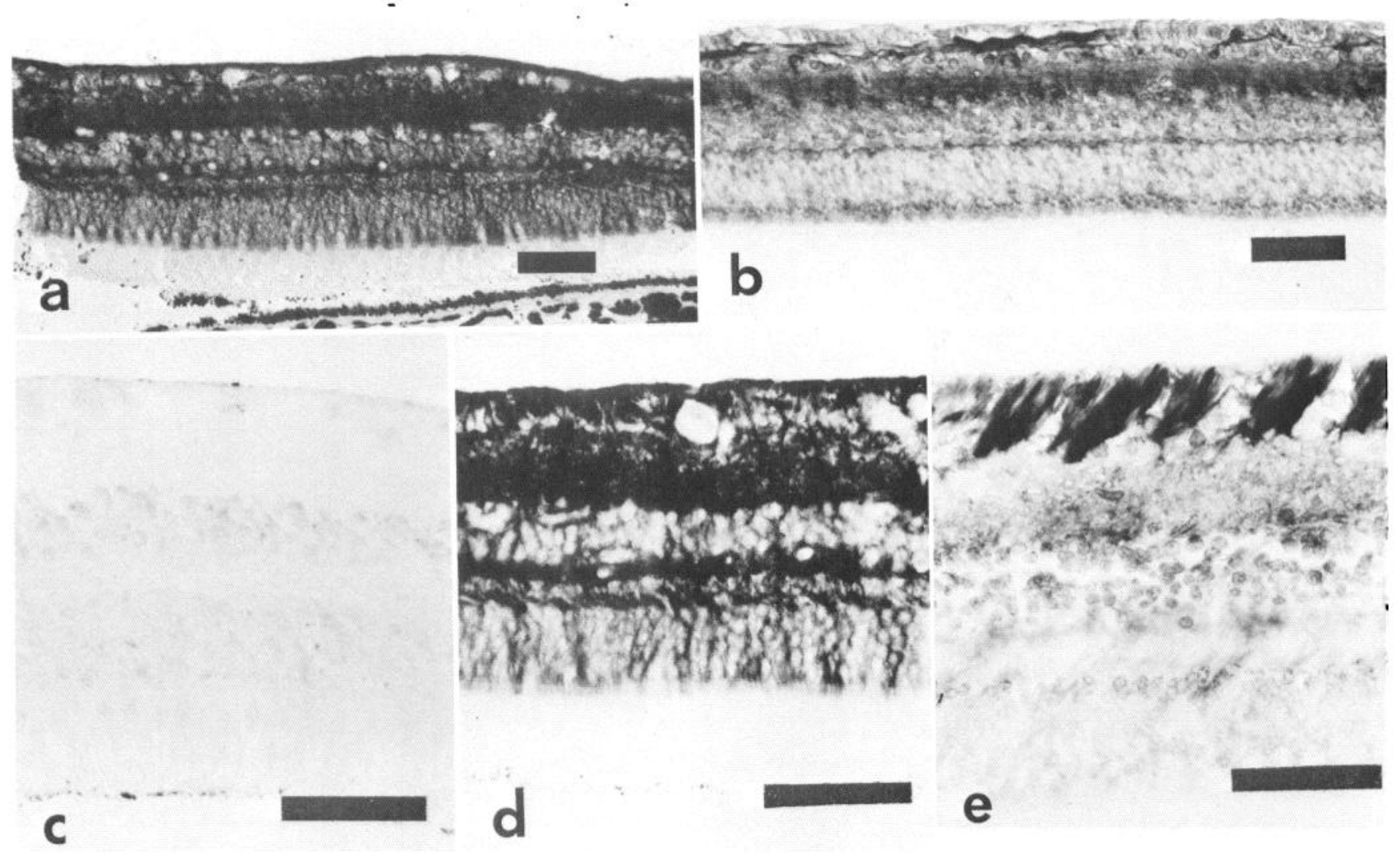

Figure 8. NGF receptor immunostaining in neural retina. Sections through retina of macaque were processed for immunocytochemistry with nonimmune mouse IgG $(c)$ or NGFR $5(a, b, d, e)$ IgG as primary antibody. Nuclei in sections in panels $b$ and $e$ were lightly counterstained with hematoxylin. Tissue is from adult $(a, c, d)$ or $135 \mathrm{~d}$ fetus $(b, e)$. Scale bars, $50 \mu \mathrm{m}$. 

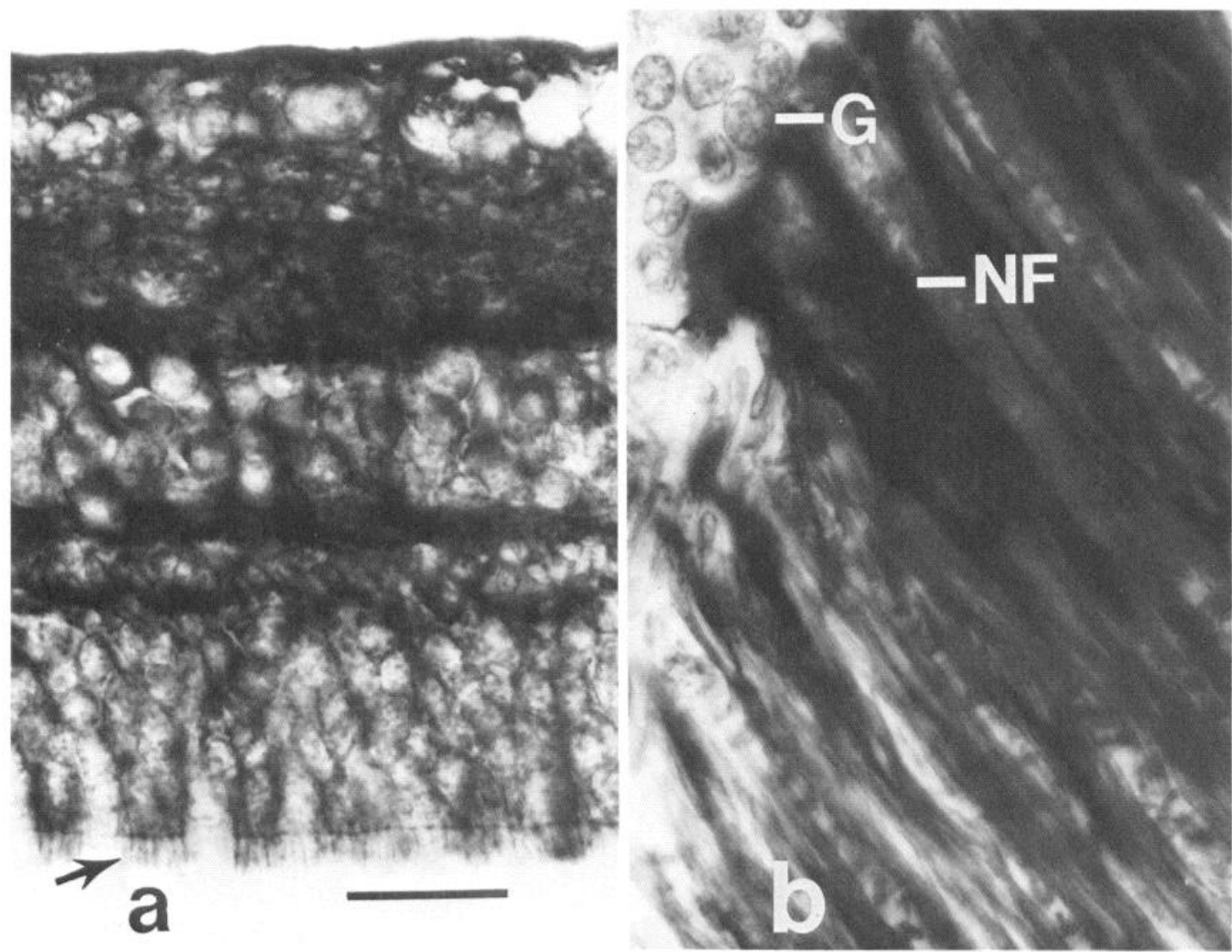

Figure 9. Detail of immunostaining in neural retina. $a$, Adult retina; arrow points to microvilli of Mueller cells. $b, 135 \mathrm{~d}$ fetus, section passing obliquely through ganglion cell and nerve fiber layers. Nuclei counterstained with hematoxylin. $G$, ganglion cell bodies; $N F$, nerve fibers. Scale bar, $20 \mu \mathrm{m}$.

levels of NGF receptor mRNA in a human astrocytoma cell line 1321N1 (Macintyre et al., 19.72). The level of NGF receptor mRNA in cerebellum decreases dramatically during the last month of gestation. A semiquantitative analysis of this developmental decrease is shown in Figure $11 B$. Twentyfold lower levels of receptor mRNA (as a fraction of total mRNA) were found in the adult cerebellum as compared with the $134 \mathrm{~d}$ fetal cerebellum. Since this analysis was performed on single individual animals, and since the linearity of hybridization data was not calibrated, these values for relative RNA levels may not be entirely accurate. However, it is clear that the developmental decrease of NGF receptor RNA levels in cerebellum is substantial.

\section{Discussion}

These studies have revealed developmentally regulated expression of NGF receptors on a limited subpopulation of CNS neurons and glia. We have extensively screened most regions of adult brain for NGF receptor immunoreactivity. Apart from the immunostaining of retina and of neurons of basal forebrain described here, the only other adult CNS tissue in which we detected NGF receptor immunoreactivity were the neuroendocrine structures - the infundibulum, tuber cinereum, hypophysis, and pineal-and brain stem and spinal cord, in which various tracts and nuclei representing central projections of primary somatosensory neurons show intense NGF receptor immunoreactivity. Our characterization of these sites of NGF re- ceptor expression has not been completed and will not be described further here.

NGF receptor immunoreactivity was found on large neurons of basal forebrain in both adult and fetus. Since rat basal forebrain neurons bearing specific binding sites for NGF appear to be predominantly, if not exclusively, cholinergic (Richardson et al., 1986), it is likely that the monkey basal forebrain neurons on which we detect NGF receptor immunoreactivity are primarily cholinergic. However, as we have not attempted to demonstrate colocalization of CAT and NGF receptor immunoreactivity, this conclusion must remain tentative.

Receptors are expressed in retina primarily in the nerve fiber layer in the fetus, possibly on glial cells but predominantly on Mueller glia in the adult. In cerebellum, receptors are present in the fetus on Purkinje cells, granule cells of the premigratory zone of the external granular layer and on neurons of the deep nuclei, while the adult cerebellum is devoid of receptors except for those associated with the vasculature.

We have tried wherever possible to verify that NGF receptor immunoreactivity detected immunocytochemically corresponds to authentic NGF receptor. In all cases, similar results were obtained using any of 3 different NGF receptor monoclonal antibodies. However, this observation is of uncertain significance since we have not yet established whether the epitopes recognized by these antibodies differ significantly. These monoclonal antibodies are indistinguishable in their specificity from monoclonal antibody ME20.4, the specificity of which we have 
Figure 10. Characterization of NGF receptor in tissue homogenates using affinity crosslinking to ${ }^{125} \mathrm{I}-\mathrm{NGF}$. Detergent homogenates of various tissues were incubated with ${ }^{125} \mathrm{I}-\mathrm{NGF}$ followed by EDAC to yield a radiolabeled NGFreceptor crosslinked complex as described in Materials and Methods. Samples were subjected to SDS-PAGE, or were first immunoprecipitated and then subjected to SDS-PAGE; dried gels were then subjected to autoradiography. A, Samples are as follows: 1, A875 melanoma cells; 2, mouse L cells; 3, dorsal root ganglion of adult macaque; 4 , cerebellum of $134 \mathrm{~d}$ macaque fetus; 5 , cerebellum of adult macaque; 6 , sample as in 4 except immunoprecipitated using NGFR $5 ; 7$, sample as in 4 except immunoprecipitated with irrelevant monoclonal antibody $\mathrm{C} 10-7$. B, All samples were obtained from adult macaque. Samples are as follows: 1 and 2 , basal forebrain; 3 and 4 , frontal cortex; 5 and 6 , liver. Samples were immunoprecipitated using irrelevant monoclonal antibody $\mathrm{C} 10-7$ (lanes $1,3,5$ ) or NFG receptor antibody NGFR5 (lanes $2,4,6)$. Positions of migration of marker proteins with the designated molecular weights are indicated.

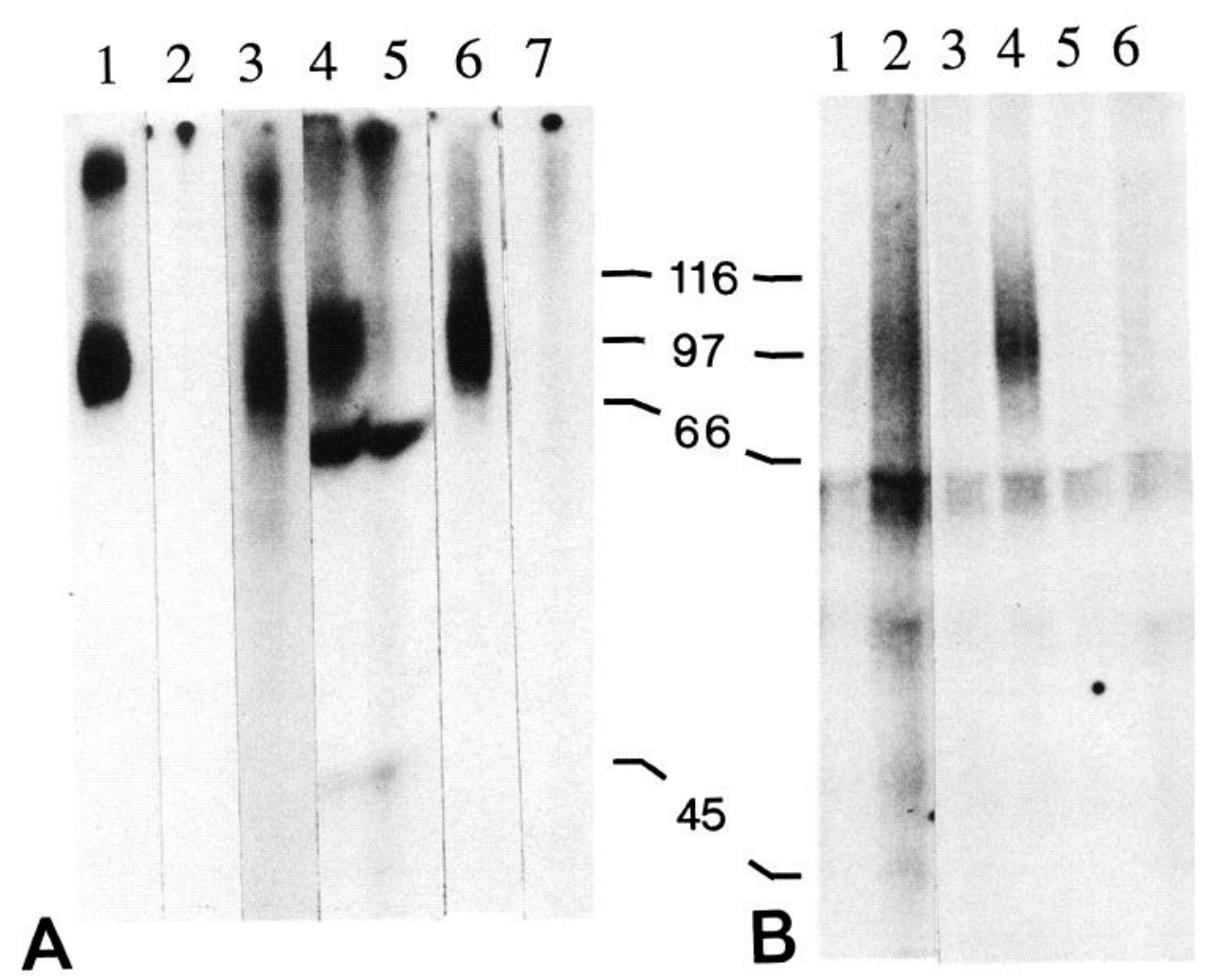

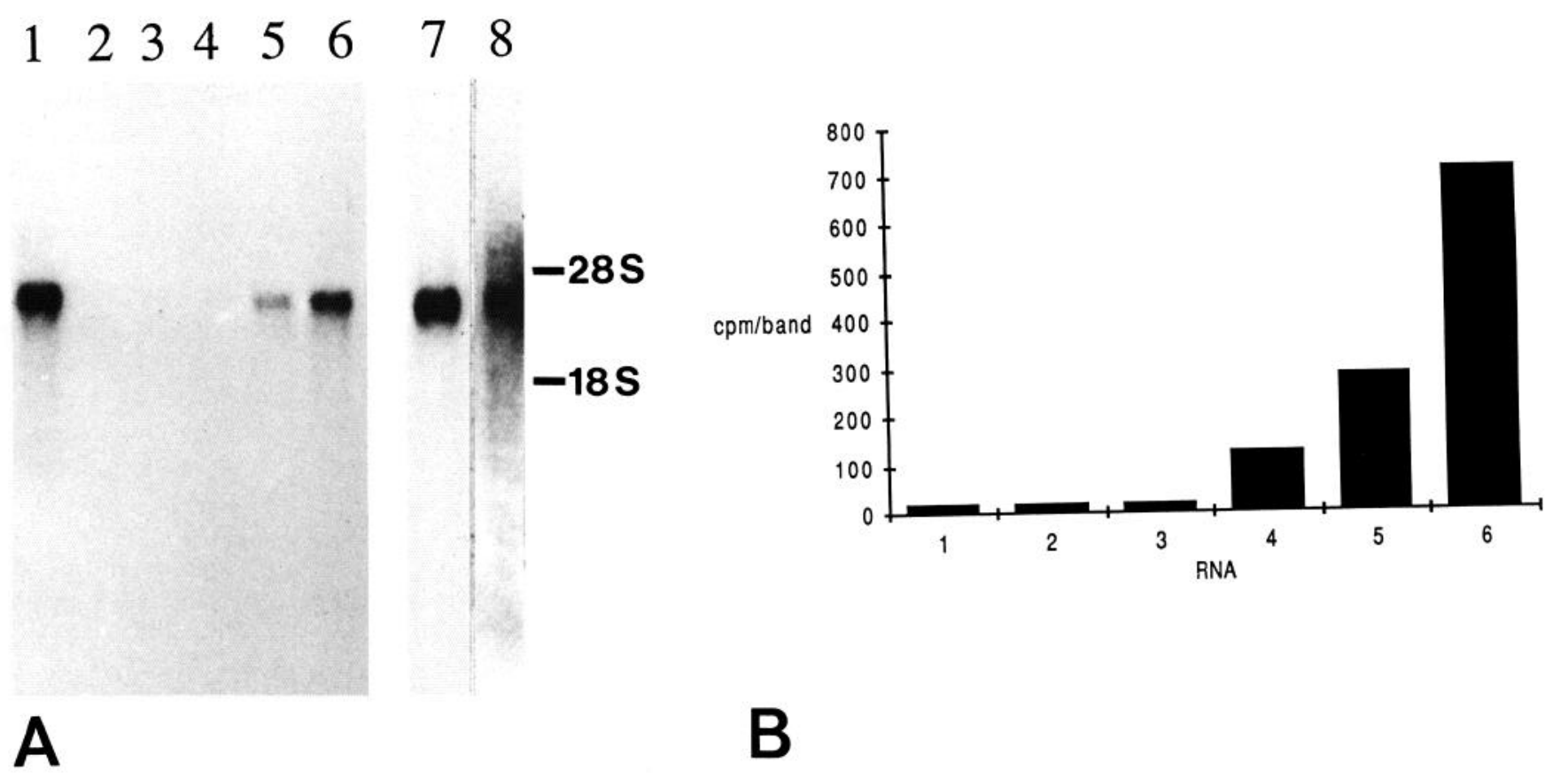

Figure 11. Northern blot analysis of NGF receptor mRNA in various tissues. $A$, RNA samples from various tissues were subjected to agarose gel electrophoresis, blotted to nitrocellulose, hybridized to a radiolabeled NGF receptor cDNA probe, and subjected to autoradiography as described in Materials and Methods. RNA samples were as follows: $1-6,25 \mu \mathrm{g}$ total cellular RNA from macaque tissues; 1 , adult dorsal root ganglia; 2 , adult cortex; 3 and 4, adult cerebellum ( 2 animals); $5,161 \mathrm{~d}$ fetal cerebellum; $6,133 \mathrm{~d}$ fetal cerebellum; $7,1.7 \mu \mathrm{g}$ poly A-containing RNA from A875 melanoma cells; $8,25 \mu \mathrm{g}$ poly A-containing RNA from human astrocytoma cell line $1321 \mathrm{~N} 1$. $B$, Regions corresponding to the 3.8 kilobase NGF receptor mRNA band of lanes 1-6 above were excised from the Northern blot depicted in $A$, and radiolabel was determined by scintillation counting as described in Materials and Methods. Values were corrected for background due to nonspecific hybridization by subtracting values from a region of the blot not corresponding to any RNA sample; 1 and 2, adult cortex; 3 , adult cerebellum; 4, $161 \mathrm{~d}$ fetal cerebellum; 5 , $133 \mathrm{~d}$ fetal cerebellum; 6 , adult dorsal root ganglia. 
described in detail (Ross et al., 1984; Grob et al., 1985; Marano et al., 1987). When NGFR5 is used to immunoprecipitate extracts of metabolically radiolabeled melanoma cell lines, or to label Western blots of extracts from melanoma cell lines, a single protein is detected that comigrates with homogeneously pure human NGF receptor (Marano et al., 1987; Marano, 1987). However, these techniques in our hands do not have the sensitivity to detcet NGF reccptor at the levels in which it is present in heterogeneous tissues such as brain, so we have been unable to employ this approach to verify that NGF receptor is the only immunoreactive species in brain tissue.

However, several lines of evidence indicate that immunostaining does represent authentic NGF receptor. In all tissues where we have detected immunocytochemical reactivity, affinity crosslinking experiments with radioiodinated NGF reveal a $100,000 \mathrm{Da}$ labeled species that is indistinguishable from authentic NGF-receptor complex. In cerebellum, levels of receptor detected by affinity crosslinking change during development in a manner similar to the developmental changes in immunocytochemical reactivity observed, and a similar developmental alteration in NGF receptor mRNA levels is also observed. Two types of evidence support the conclusion that immunoreactivity detected on glial cell types such as retinal Mueller cells represents authentic NGF receptor. First, we have demonstrated that the human astrocytic cell line $1321 \mathrm{~N} 21$ expresses the NGF receptor mRNA. Also, we have recently detected the presence of NGF receptors on the rat $\mathrm{C} 6$ astrocytoma cell line, using the NGF affinity crosslinking technique (A. Balliet, unpublished observations). Second, recently we have observed that a monoclonal antibody to rat NGF receptor (Chandler et al., 1984) specifically stains Mueller cells of rat retina (S. L. Patterson, work in progress). The rat NGF receptor antibody appears to recognize a region of the NGF receptor different from that recognized by the antibodies to the human receptor since the rat receptor antibody enhances NGF binding (Chandler et al., 1984), while the human antibody blocks NGF binding (Ross et al., 1984). Because the antibodies apparently recognize different receptor sites, it is unlikely that any spuriously cross-reacting protein would be recognized by both antibodies.

Our results suggest that NGF-responsive magnocellular cholinergic neurons of the basal forebrain are reactive with antibodies originally generated against the NGF receptor of human melanoma cells, and which recognize the NGF receptor of peripheral neurons. This result is in excellent agreement with similar studies performed independently by Hefti et al. (1986) on human tissue. Thus, it appears likely that the NGF response of brain magnoccllular cholincrgic neurons is mediated by an NGF receptor protein that is similar, if not identical, to the NGF receptor of the PNS. Neither we nor Hefti et al. have attempted to demonstrate colocalization of NGF receptor and CAT on basal forebrain neurons. It is desirable that this be done in the future so that it may be determined whether the populations of cholinergic and NGF receptor-bearing neurons are identical. As were Hefti et al., we were unable to detect NGF receptors on the cortical and hippocampal projections of basal forebrain cholinergic neurons, presumably because the sensitivity of our immunocytochemical procedure is insufficient to visualize receptors on such diffusely distributed fine fibers. Also in agreement with Hefti et al., we find the NGF receptor immunoreactivity associated with neuronal cell bodies to be localized not only on the cell surface, but in the intracellular perinuclear region. The extensive intracellular immunoreactivity is similar to that ob- served in Purkinje cells as shown here, and in sensory and sympathetic neurons (G. C. Schatteman, unpublished observations). It presumably corresponds to an extensive intracellular pool of receptors on membranous organelles destined for transport to axon terminii.

While striatal cholinergic interneurons of newborn rat appear to be responsive to NGF (Mobley et al., 1985) and specific highaffinity binding of NGF to striatal neurons of adult rat has been reported by Richardson et al. (1986), we were unable to detect NGF receptor immunoreactivity on these neurons in adult primate. We do not know whether this represents a limitation of the sensitivity of the immunocytochemical methodology or a difference between species in NGF receptor expression.

The extremely limited distribution of NGF receptors on brain neurons detected by immunocytochemistry contrasts with the conclusion of Taniuchi et al. (1986) that receptors are very broadly distributed in adult rat brain. These investigators based their assessment on results obtained using a method of assaying NGF receptor in detergent extracts of brain tissue very similar to the method we have described. In fact, our results using this procedure are in general agreement with Taniuchi et al. However, it is our view that the NGF receptor detected in most regions of the brain is primarily derived from the vasculature. Taniuchi et al. considered this possibility and rejected it, because they found no reduction of receptor levels following destruction of the sympathetic innervation of the brain vasculature. However, their conclusion was based on the assumption that vascular NGF receptor would be associated exclusively with sympathetic axons. Our immunocytochemical results indicate that Schwann cells associated with sympathetic nerve fibers have abundant NGF receptors (Ross et al., 1984; G. C. Schatteman, unpublished observations). These Schwann cells probably would not be eliminated by the procedures employed by Taniuchi et al. Also, in some cases, NGF receptor immunoreactivity is present on vascular pericytes (G. C. Schatteman et al., unpublished observations).

The presence of NGF receptors on developing cerebellar neurons raises the question of whether these cells would be exposed to NGF. Subsequent to our observation of cerebellar NGF receptor expression, a report appeared in which cerebellum was singled out as a brain region in which relatively high levels of NGF are present in the absence of any known NGF responsive neuronal population (Large et al., 1986). These investigators found also that, in rat cerebellum, NGF levels and NGF mRNA levels were highest during the first $20 \mathrm{~d}$ of postnatal development. This period represents a stage of rat cerebellar development roughly comparable to the late prenatal period of primate cerebellar development during which we observe expression of NGF receptors. Thus, it appears likely that NGF within the cerebellum may provide trophic support for NGF receptor-bearing cerebellar neurons: Purkinje cells, nascent granule cells, and neurons of the deep cerebellar nuclei. This possibility must be explored. It is interesting to note that Wille et al. (1986) have demonstrated by in situ hybridization that granule cells in the external granular layer of developing rat cerebellum initiate expression of the cellular fos and myc $m$ RNAs at the same stage of development at which we detect expression of NGF receptor. In the rat $\mathrm{PC} 12$ cell line, NGF induces expression of cellular fos and myc mRNAs (Curran and Morgan, 1985; Greenberg et al., 1985; Kruijer et al., 1985). Also, Choung et al. (1987) report that $\mathrm{Ng}$-CAM is expressed specifically on the granule cells of the premigratory zone of the external granular layer. Ng-CAM 
(Ll, NILE) also is induced in PC12 cells in response to NGF (McGuire et al., 1978; Bock et al., 1985; Friedlander et al., 1986). Thus, we speculate that, in developing cerebellum, induction of expression of NGF receptors on granule cells leads to NGF induced expression of fos, myc, and Ng-CAM.

The presence of NGF receptors in retinal Mueller cells (a modified astrocyte type), in several astrocytic cell lines, and possibly on glia of retinal nerve fibers is surprising, but it is reminiscent of the localization of receptors in Schwann cells (Ross et al., 1984). It is important to note that no NGF receptor immunoreactivity was detected on glia in most CNS regions. The expression of NGF receptors in a diverse subset of glial cell types suggests that some common functional role may exist. In amphibians, optic nerve regeneration has been shown to be stimulated by NGF. While it has generally been presumed that this is due to response of retinal ganglion cells to NGF, it has been suggested that associated glial cells may also be responsive to NGF (Glaze and Turner, 1978). Thus, the biological effects of NGF in this system may be mediated, at least in part, indirectly through glia.

The observation that NGF receptors are expressed only transiently during cerebellar development suggests that NGF receptors may be expressed elsewhere in the brain during limited periods of fetal development. Cerebellar development lags behind the development of much of the rest of the brain in rodents and primates. Thus, NGF receptor expression and functional responses to NGF should be sought in various brain areas during relatively early stages of fetal development when neuroblast proliferation and neuronal migration are actively underway.

\section{References}

Altman, J. (1972) Postnatal development of the cerebellar cortex in the rat. J. Comp. Neurol. 145: 353-398.

Aviv, H., and P. Leder (1972) Purification of biologically active globin messenger RNA by chromatography on oligothymidylic acid-cellulose. Proc. Natl. Acad. Sci. USA 69: 1408-1412.

Bock, E., C. Richter-Landsberg, A. Faissner, and M. Schachner (1985) Demonstration of immunochemical identity between the nerve growth factor-inducible large internal (NILE) glycoprotein and the cell adhesion molecule Ll. EMBO J. 4: 2765-2768.

Chandler, C. E., L. M. Parsons, M. Hosang, and E. M. Shooter (1984) A monoclonal antibody modulates the interaction of nerve growth factor with PC12 cells. J. Biol. Chem. 259: 6882-6889.

Chirgwin, J. M., A. A. Przbyla, R. J. MacDunald, and W. J. Rutter (1979) Isolation of biologically active ribonucleic acid from sources enriched in ribonuclease. Biochemistry 18: 5294-5299.

Chuong, C.-M., K. L. Crossin, and G. M. Edelman (1987) Sequential expression and differential function of multiple adhesion molecules during the formation of cerebellar cortical layers. J. Cell Biol. 104: 331-342.

Curran, T., and J. T. Morgan (1985) Superinduction of the c-fos protooncogene by nerve growth factor in the presence of peripherally active benzodiazapines. Science 229: 1265-1268.

Feramisco, J. R., D. M. Helman, J. E. Smart, K. Burridge, and G. P. Thomas (1982) Co-existence of vinculin-like protein of higher molecular weight in smooth muscle. J. Biol. Chem. 257: 11024-11031.

Friedlander, D. R., M. Grumet, and G. M. Edelman (1986) Nerve growth factor enhances expression of neuron-glia cell adhesion molecule in PC12 cells. J. Cell Biol. 102: 413-419.

Glaze, K. A., and J. E. Turner (1978) Regenerative repair in the severed optic nerve of the newt (Triturus viridescens): Effect of nerve growth factor antiserum. Exptl. Neurol. 58: 500-510.

Gnahn, H., F. Hefti, R. Heumann, M. Schwab, and H. Thoenen (1983) NGF-mediated increase of choline acetyltransferase (ChAT) in the neonatal forebrain: Evidence for a physiological role of NGF in the brain? Dev. Brain Res. 9: 45-52.

Greenberg, M. E., L. A. Greene, and E. B. Ziff (1985) Nerve growth factor and epidermal growth factor induce rapid transient changes in proto-oncogene transcription in PC1 2 cells. J. Biol. Chem. 260: 1410114110 .

Grob, P. M., A. H. Ross, H. Koprowski, and M. Bothwell (1985) Characterization of the human melanoma nerve growth factor receptor. J. Biol. Chem. 260: 8044-8049.

Hefti, F., J. Hartikka, F. Eckstein, H. Gnahn, R. Heumann, and M. Schwab (1985) Nervc growth factor (NGF) increases choline acetyltransferase but not survival or fiber growth of cultured septal cholinergic neurons. Neuroscience 14: 55-68.

Hefti, F., J. Hartikka, A. Salvatierra, W. J. Weiner, and D. Mash (1986) Localization of nerve growth factor receptors in cholinergic neurons of the human basal forebrain. Neurosci. Lett. 69: 37-41.

Honegger, P., and D. Lenoir (1982) Nerve growth factor (NGF) stimulation of cholinergic telencephalic neurons in aggregating cell cultures. Dev. Brain Res. 3: 229-238.

Johnson, D., A. Lanahan, C. R. Buck, A. Sehgal, C. Morgan, E. Mercer, M. Bothwell, and M. Chao (1986) Expression and structure of the human NGF receptor. Cell 47: 545-554.

Korshing, S., G. Auburger, R. Heumann, J. Scott, and H. Thoenen (1985) Levels of nerve growth factor and its mRNA in the central nervous system of the rat correlate with cholinergic innervation. EMBO J 4: 1389-1393.

Kruijer, W., D. Schubert, and I. M. Verma (1985) Induction of the proto-oncogene fos by nerve growth factor. Proc. Natl. Acad. Sci. USA $82: 7330-7334$.

Laemmli, U. K. (1970) Cleavage of structural proteins during the assembly of the head of bacteriophage T4. Nature 227:680-685.

Large, T. H., S. C. Bodary, D. O. Clegg, G. Weskamp, U. Otten, and L. F. Reichardt (1986) Nerve growth factor gene expression in the developing rat brain. Science 234: 352-355.

Lehrach, H., D. Diamond, J. M. Wozney, and H. Boedtker (1977) RNA molecular weight determinations by gel electrophoresis under denaturing conditions, a critical reexamination. Biochemistry 16:47434751 .

Levi-Montalcini, R., and L. Aloe (1985) Differentiating effects of murine nerve growth factor in the peripheral and central nervous systems of Xenopus laevis tadpoles. Proc. Natl. Acad. Sci. USA 82: $7111-$ 7115.

Macintyre, E. H., J. Ponten, and A. E. Vatter (1972) The ultrastructure of human and murine astrocytes and of human fibroblasts in culture. Acta Pathol. Microbiol. Scand. A 80:267-283.

Marano, N. (1987) Purification and characterization of the human melanoma nerve growth factor receptor. Doctoral thesis, Princeton University, Princeton, NJ.

Marano, N., B. Dietzschold, J. J. Earley, Jr., G. Schatteman, S. Thompson, P. Grob, A. H. Ross, M. Bothwell, B. F. Atkinson, and H. Koprowski (1987) Purification and amino terminal sequencing of human melanoma nerve growth factor receptor. J. Neurochem. 48: 225-232.

Martinez, H. J., C. F. Dreyfus, G. M. Jonakait, and I. B. Black (1985) Nerve growth factor promotes cholinergic development in brain striatal cultures. Proc. Natl. Acad. Sci. USA 82: 7777-7781.

McGuire, J. C., L. A. Greene, and A. V. Furano (1978) NGF stimulates incorporation of focuse or glucosamine into an external glycoprotein in cultured rat PCl2 pheochromocytoma cells. Cell 15: 357-365.

Mobley, W. C., J. L. Rutkowski, G. I. Tennekoon, K. Buchanan, and M. V. Johnston (1985) Choline acetyltransferase activity in striatum of neonatal rats increased by nerve growth factor. Science 229: 284286.

Richardson, P. M., V. M. K. Verge Issa, and R. J. Riopelle (1986) Distribution of neuronal receptors for nerve growth factor in the rat. J. Neurosci. 6: 2312-2321.

Rigby, P. W. J., M. Dieckmann, C. Rhodes, and P. Berg (1977) Labelling deoxyribonucleic acid to high specific activity in vitro by nick translation with DNA polymerase I. J. Mol. Biol. 113: 237-251.

Ross, A. H., P. Grob, M. Bothwell, D. E. Elder, C. S. Ernst, N. Marano, B. F. D. Ghrist, C. C. Slemp, M. Herlyn, B. Atkinson, and H. Koprowski (1984) Characterization of nerve growth factor receptor in neural crest tumors using monoclonal antibodies. Proc. Natl. Acad. Sci. USA 81: 6681-6685.

Schechter, A. L., and M. A. Bothwell (1981) Nerve growth factor receptors on PC1 2 cells: Evidence for two receptor classes with two differing cytoskeletal associations. Cell 24: 867-874.

Sedmak, J. J., and S. E. Grossberg (1977) A rapid, sensitive, and versatile assay for protein using Coomassie brilliant blue G250. Anal. Biochem. 79: 544-552. 
Seiler, M., and M. E. Schwab (1984) Specific retrograde transport of nerve growth factor (NGF) from neocortex to nucleus basalis in the rat. Brain Res. 300: 33-36.

Shelton, D. L., and L. F. Reichardt (1984) Expression of the B-nerve growth factor gene correlates with the density of sympathetic innervation in effector organs. Proc. Natl. Acad. Sci. USA 81: 7951-7955.

Shelton, D. L., and L. F. Reichardt (1986) Studies on the expression of the nerve growth factor (NGF) gene in the central nervous system: Level and regional distribution of NGF mRNA suggests that NGF functions as a trophic factor for several distinct populations of neurons. Proc. Natl. Acad. Sci. USA 83: 2714-2718.

Taniuchi, M., J. B. Schweitzer, and E. M. Johnson, Jr. (1986) Nerve growth factor receptor molecules in rat brain. Proc. Natl. Acad. Sci. USA 83: 1950-1954.

Thomas, P. S. (1980) Hybridization of denatured RNA and small DNA fragments transferred to nitrocellulose. Proc. Natl. Acad. Sci. USA $77: 5201-5205$.

Turner, J. E., and K. A. Glaze (1977) Regenerative repair in the severed optic nerve of the newt (Triturus viridescens): Effect of nerve growth factor. Exp. Neurol. 57: 687-697.

Wille, W., D. Goldowitz, and C. Ruppert (1986) Regulation of c-myc and c-fos proto-oncogenes during mouse cerebellar development. Neurosci. Abstr. 12: 216. 